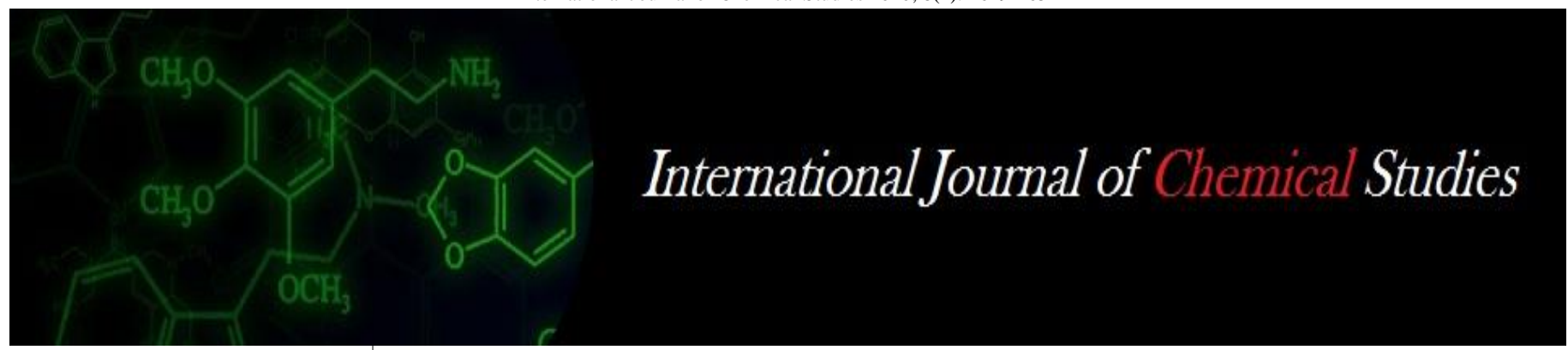

P-ISSN: 2349-8528

E-ISSN: 2321-4902

www.chemijournal.com

IJCS 2020; 8(4): 1649-1654

(C) 2020 IJCS

Received: 22-05-2020

Accepted: 24-06-2020

\section{Mukesh Kumar}

Department of Agronomy, CCS Haryana Agricultural

University, Hisar, Haryana, India

\section{Bhagat Singh}

Department of Agronomy,

CCS Haryana Agricultural

University, Hisar, Haryana,

India
Corresponding Author:

Mukesh Kumar

Department of Agronomy, CCS Haryana Agricultural

University, Hisar, Haryana, India

\section{Evaluation of irrigation levels and hydrogels on the growth, yield and profitability of wheat}

\section{Mukesh Kumar and Bhagat Singh}

\author{
DOI: $\underline{\text { https://doi.org/10.22271/chemi.2020.v8.i4p.9846 }}$
}

\begin{abstract}
A field experiment was carried out during Rabi season of 2016-17 and 2017-18 at CCS Haryana Agricultural University, Hisar (Lat. $29^{\circ} 10^{\prime} \mathrm{N}$, Log. $75^{\circ} 46^{\prime} \mathrm{E}$ and $215.2 \mathrm{~m}$ amsl) to investigate the effect of irrigation levels and hydrogels on the growth, yield and profitability of wheat. The soil of the field was sandy loam in texture, slightly alkaline in $\mathrm{pH}$ (7.9), low in organic carbon, poor in available nitrogen and medium in available phosphorus and available potassium. The experiment was laid out in split plot design with four irrigation levels viz., no irrigation (control), three irrigations at crown root initiation (CRI), late tillering (LT) and grain filling (GF) stage, three irrigations at 35/40 days after sowing (DAS), 80 and 120 DAS and six irrigations at critical stages i.e. CRI, tillering, jointing, flowering, milking and dough stage in main plot and three moisture conservation practices viz. control (no hydrogel), Pusa Hydrogel @ $2.5 \mathrm{~kg} / \mathrm{ha}$ and Herbal Hydrogel (Gum Tragacantha i.e. Goond katira) seed treatment in subplots, replicated thrice. Pooled results of two consecutive year, 2016-17 and 2017-18 revealed that progressive increase in wheat grain yield and biological yield was recorded with every increment in irrigation frequency. Six irrigations brought significantly higher grain yield $(62.11 \mathrm{q} / \mathrm{ha})$ over no irrigation (36.94 q/ha), three irrigation at CRI, LT and GF (52.90 q/ha) and three irrigations at 35/40, 80 and 120 DAS (55.87 q/ha). Maximum grain yield in six irrigated crop might be due to significantly more growth and yield attributes viz., plant height $(100.94 \mathrm{~cm})$, effective tillers $/ \mathrm{m}^{2}(406.67)$, grains/earhead (59.43) and 1000-grain weight $(39.53 \mathrm{~g})$ in six irrigated crop then other irrigation regimes. Six irrigated crop produced $40.52,14.83$ and $10.05 \%$ more grain yield than control, three irrigation at CRI, LT and GF stage and three irrigation at 40,80 and 120 DAS. Among different moisture conservation treatments, the application of Pusa hydrogel and herbal hydrogel had not improved grain yield of wheat significantly as compared to control (without hydrogel). Although Pusa Hydrogel treatment produced numerically higher grain yield $(52.55 \mathrm{q} / \mathrm{ha})$ and yield attributes then control $(51.31 \mathrm{q} / \mathrm{ha})$ and Herbal Hydrogel $(52.01 \mathrm{q} / \mathrm{ha})$. Application of six irrigation at all important crop growth stages provided additional gross return (Rs. 53001/ha) and net returns (Rs. 45688/ha) over without irrigation. The highest grain yield was recorded when six irrigations were applied at all the critical growth stages and application of Pusa hydrogel and herbal hydrogel had not improved grain yield of wheat.
\end{abstract}

Keywords: Wheat, hydrogel, irrigation, economics, grain yield

\section{Introduction}

Wheat is the world's most widely cultivated cereal crop which ranks first followed by rice and it is more preferable than rice for its higher seed protein content. Wheat is grown on about $29.55 \mathrm{mha}$ in India with production of $101.20 \mathrm{mt}$ in $2018-19$ and an average yield of 3424 $\mathrm{kg} / \mathrm{ha}$. There are considerable yield gaps between the major wheat-growing states in the country with highest yield recorded in Punjab (5077 kg/ha) followed by Haryana (4643 kg/ha) and lowest in Maharashtra (1275 kg/ha) [ICAR-IIWBR, 2019].

Water availability is one of the most important factors influencing the growth and productivity of wheat. Water requirement of wheat vary from 180-420 mm depending upon the duration of the crop (Dar and Ram, 2016) ${ }^{[3]}$. There is a huge scope to realise what minimum amount of water should be applied to have maximum yield per unit of water applied. Yield of wheat increased significantly with increased levels of irrigation (Kumar et al., 2018) ${ }^{[9]}$. All stages of crop growth are not uniformly susceptible to water scarcity. Some stages can cope-up with water shortage very well, while others are more susceptible and water shortages at such stages may result in large quantity of yield losses. Moisture stress is known to reduce biomass, tillering ability, grain number per spike and grain size at any stage when it occurs. 
So, the overall effect of moisture stress depends on intensity and length of stress (Mogaddam et al., 2012) ${ }^{[13]}$.

Hydrogel is one of the most popular gels, used to increase infiltration rates in field agriculture, in addition to increasing water holding capacity for agricultural applications (Dar and Ram, 2016) ${ }^{[3]}$. Hydrogels are cross linked polymers that can absorbed 400-1500 times their dry weight in water, due to network space created by its cross linked structure (Singh et al., 2018) ${ }^{[19]}$. Notably, its swelling ratio increased with the rise in temperature up to $50{ }^{\circ} \mathrm{C}$ without any adverse effect on the polymer matrix structure. It enhances the crop productivity per unit available of water and nutrients, particularly in moisture stress condition. It also improves physical properties of soil, seed germination, seedling emergence rate, root growth and density that help plants to prolonged moisture stress (Ekebafe et al., 2011) ${ }^{[4]}$. Hydrogel reduces the leaching of herbicide, fertilizer and requirements of irrigation for crops. It also promotes early dense flowering and tillering and delay the permanent wilting point (Mehr and Kourosh, 2008) ${ }^{[12]}$. These synthetic polymers found in form of crystals and available under several trade names viz., Super Absorbent, Pusa Hydrogel etc. are collectively called hydrogel. 'Pusa Hydrogel' is a novel semi-synthetic super absorbent polymer developed by the Indian Agricultural Research Institute (IARI) has shown the potential to realize more yield per unit of input. Pusa hydrogel also improves soil hydro-physical properties such as porosity, aggregate stability and hydraulic conductivity (Dabhi et al., 2013) ${ }^{[2]}$. A significant improvement in yield and water use efficiency in most of the test crops was reported by application of Pusa hydrogel (Anupama and Parmar, 2012) ${ }^{[1]}$.

Herbal Hydrogel in agriculture ensure better crop productivity in moisture stress condition by delaying permanent wilting point of the seedling \& application of delayed first irrigation and overall less irrigation make the crop nearly weeds free. Herbal Hydrogel Technology saved significant irrigation water by producing more crops per drop of water, reduced cost of cultivation and used fewer resources (fertilizers, chemicals, water, power, labor) without any plenty on seed yield and environmental gains as well and also make it feasible to grow rice crop successfully in rainfed hill ecology and sandy soils of Semi Arid Regions of North India and shown potential for its use in other parts of the world having similar ecology (Lather, 2019) [11]. Because of the unpredictable monsoon and water availability for farming, crops across the country suffer due to either excess water in the fields or inadequate water. The gel mitigates the risks, if the water availability drops. Two irrigations in wheat can be saved by application of hydrogel without compromising the grain yield (Roy et al., 2019) ${ }^{[17]}$. Keeping these points in mind, the present investigation was carried out to examine the influence of Pusa and Herbal hydrogel on growth, yield attributes, yield and economics of wheat under different irrigation levels.

\section{Materials and Methods}

A field experiment was carried out during the Rabi season of 2016-17 and 2017-18 at Research Farm of Wheat \& Barley Section, Department of Genetics \& Plant breeding, CCS HAU, Hisar, Haryana (India) situated at $29^{\circ} 10^{\prime} \mathrm{N}$ latitude and $75^{\circ} 46^{\prime} \mathrm{E}$ longitude at an elevation of $215.2 \mathrm{~m}$ above mean sea level. The soil of experimental site was sandy loam in texture, having a $\mathrm{pH} 7.9$, electrical conductivity $0.27 \mathrm{dS} / \mathrm{m}$, low organic carbon 0.27 per cent, available low N $126 \mathrm{~kg} / \mathrm{ha}$, available medium $\mathrm{P} 12.3 \mathrm{~kg} / \mathrm{ha}$ and $\mathrm{K} 328 \mathrm{~kg} / \mathrm{ha}$. The experiment was laid out in split plot design with four irrigation levels viz., no irrigation, three irrigation at crown root initiation (CRI), late tillering (LT) and grain filling (GF) stage, six irrigations at CRI, tillering, jointing, flowering, milking and dough stage and three irrigations at 35/40 DAS, 80 and 120 DAS in main plot and three moisture conservation practices viz. control (no hydrogel), Pusa Hydrogel @ 2.5 $\mathrm{kg} / \mathrm{ha}$ and Herbal Hydrogel (Gum Tragacantha i.e. Goond katira) seed treatment in subplots, replicated thrice. To carry out the experiment the land preparation operation viz. pre sowing irrigation, ploughing and levelling were done. Wheat variety, WH 1105 was sown with a recommended seed rate of $100 \mathrm{~kg} / \mathrm{ha}$ on $11^{\text {th }}$ November, 2016 during first year and on $12^{\text {th }}$ November, 2017 during second year. The recommended dose of nitrogen, phosphorus and potash was 150-60-40 $\mathrm{kg} / \mathrm{ha}$, respectively, which was applied through urea $(46 \% \mathrm{~N})$, single superphosphate $\left(16 \% \quad \mathrm{P}_{2} \mathrm{O}_{5}\right)$ and muriate of potash $\left(60 \% \mathrm{~K}_{2} \mathrm{O}\right)$. The basal fertilizers in all the treatments including all the $\mathrm{P}$ and $\mathrm{K}$ fertilizers and $1 / 3 \mathrm{~N}$ fertilizer were applied before wheat sowing, remaining the $2 / 3$ dose of $N$ fertilizer was applied as top-dressed in two splits, $1 / 3$ at the time of first irrigation and $1 / 3 \mathrm{rd}$ at second irrigation. Pusa Hydrogel at the rate of $2.5 \mathrm{~kg} / \mathrm{ha}$ well mixed with sufficient quantity of soil was applied to allotted experimental plots in furrows just before the sowing of crops. While, Herbal hydrogel applied in the form of seed treatment at the time of sowing of the crop. Other management practices including irrigation, weeding and hoeing were adopted as per package and practices of wheat crop. Yield attributing parameters were recorded at the time of harvest. Five plants were selected randomly from each treatment to record the observations of yield attributing characters. The crop was harvested on $4^{\text {th }}$ April, 2017 and $9^{\text {th }}$ April, 2018 during first and second year, respectively. The data were analysed using appropriate analysis of variance (ANOVA) technique (Gomez and Gomez, 1984) ${ }^{[5]}$. The net returns of different treatments were calculated by subtracting the total cost of cultivation from gross returns of respective treatments and the benefit cost ratio was calculated by dividing the gross returns with total cost of cultivation.

\section{Results and Discussion Growth parameters}

Plant height: Irrigation levels had significant affect on plant height (Table 1). Maximum plant height was recorded with the application of six irrigation which is significantly higher than lower levels of irrigation and minimum plant height was recorded in control i.e. no irrigation treatment. The plant height increased with increase in number of irrigations significantly because of more and regular availability of water to the entire crop growth season. The higher amount of available water kept the higher turgor potential, which lead to higher rate of photosynthesis due to more opening of stomata for longer period of time. This increased the rate of cell division and enlargement, which leads to higher growth rate (Mukesh and Pannu, 2014) ${ }^{[14]}$. Water is fundamental constituents of plant protoplasm and its adequate supply is essential for cell division and cell elongation. Therefore, optimum availability of water with application of six irrigations to wheat might improve photosynthetic area of plants that cumulatively contributed to higher plant height (Kumar et al., 2019) ${ }^{[10]}$. No significant difference was observed between the control and the hydrogel applied treatments in terms of plant height of wheat crop 


\section{Yield attributing characters}

Effective tillers $/ \mathbf{m}^{2}$ : Number of effective tillers increased significantly with increased levels of irrigation (Table 1). Maximum number of effective tillers $/ \mathrm{m}^{2}$ recorded with the application of six irrigation and it improved 36.44, 10.04 and $7.58 \%$ over no irrigation, three irrigations (CRI, LT and GF) and three irrigations (40, 80 and 120 DAS). This is due to regular supply of water in all the crop growth stages, it maintains sufficient moisture and more uptakes of nutrients for better growth and development that improve its photosynthetic efficiency by improving source sink relationship of the plant leading higher growth and development reflected by higher yield attributing characters of the plant. Similar findings have been reported by Kumar et al. (2019) ${ }^{[10]}$. Frequent supply of irrigation might have been responsible for better pollen maturity and fertilization with six irrigations at CRI, TL, JT, FL, MI and Dough stage resulted greater number of effective tillers $/ \mathrm{m}^{2}$ as compared to lower frequencies of irrigation or without irrigation treatments. These results are in agreement with findings of Gora et al. (2017) ${ }^{[6]}$. Different hydrogels treatment had not influenced the effective tillers $/ \mathrm{m}^{2}$.

Grains/ear head: Number of grains/ear head also increased significantly with increased irrigation levels (Table 1). The highest number of grains/ ear head recorded with the application of six irrigations and it increased to the tune of $13.12,6.73$ and $3.93 \%$ over without irrigation, three irrigations (CRI, LT and GF) and three irrigations (40, 80 and 120 DAS) applied crop. The more number of grains/ear head is more in six irrigated crop might be due to regular supply of water in the crop at all the crop growth stages, it maintains sufficient moisture and more uptakes of nutrients for better growth and development that improve its photosynthetic efficiency by improving source sink relationship of the plant leading higher growth and development reflected by more grains/ ear head of the plant. Similar results have been reported by Kumar et al. (2019) ${ }^{[10]}$. Ngwako and Mashiqa (2013) ${ }^{[16]}$ also found that irrigation throughout the growth stages recorded the more gains/ear head. Grains/ear head also not influenced significantly with the application of Pusa and Herbal hydrogels.

1000-grain weight: Irrigation levels showed significant affect on 1000-grain weight (Table 1). Boldest grain (39.53 g) was obtained with the application of six irrigations followed by three irrigations at 40, 80 and 120 DAS (39.07 g) and minimum was recorded in without irrigation treatment $(37.53$ g). The more test weight in six irrigated crop might be due to regular supply of water in the crop, which accelerate process of photosynthesis, ultimately resulting into accumulation and translocation of more photosynthates from source to sink which might be helping in increasing the size and weight of kernel resulting into higher test weight of grains instead of less irrigated crop. Taipodia and Singh (2013) [20] also reported that 1000 grain weight was significantly affected by different irrigation levels and maximum test weight obtained with 6 irrigations. Test weight was not affected by Pusa and herbal hydrogel treatments during both years of study.

Grain and Biological yield: Grain yield and biological yield increased significantly with increased levels of irrigation (Table $1 \& 2$ ). Under irrigation treatments there was a progressive increase in wheat grain yield with every increment in irrigation level. Six irrigated crop produced
$62.11 \mathrm{q} / \mathrm{ha}$ grain yield, which is significantly higher than lower frequencies of irrigation and it recorded 40.52, 14.83 and $10.04 \%$ more grain yield over without irrigation, three irrigations (CRI, LT and GF) and three irrigations (40, 80 and 120 DAS) applied crop. Similar like grain yield, six irrigation at CRI, TL, JT, FL, MI and dough stage produced 61.82, 16.72 and $13.95 \mathrm{q} /$ ha more biological yield (146.54 q/ha) than without irrigation, three irrigations (CRI, LT and GF) and three irrigations (40, 80 and 120 DAS) applied crop. Inadequate water supply (irrigation) resulted in water stress for the crop. This resulted in reduced number of tillers, fertile spikelets, and grains, as well as grain weight (Karim et al., 2000) ${ }^{[8]}$. Shirazi et al. (2014) ${ }^{[18]}$ also reported that irrigation regimes have significant effect on grain yield and growth parameters of wheat. Kumar et al. (2019) ${ }^{[10]}$ also reported that optimum availability of water with application of six irrigations to wheat might have improved the photosynthetic area of plants that cumulatively contributed to higher plant height, dry matter accumulation and CGR of crop.

The significant increase in grain and biological yield increased with the increase in irrigation levels. The higher irrigation frequency fulfilled the timely crop water requirement, which resulted into better growth in term of plant height, which maintained better plant relations, which helped in opening of stomata and increased rate of photosynthesis which ultimately resulted in higher grain yield. The significantly positive association between biological yield with growth parameter namely plant height $(\mathrm{r}=0.99 * *)$. The higher growth finally resulted into significant increase in grain yield through yield attributes namely number of effective tillers, number of grains per spike and test weight. The increase in yield attributes by irrigation frequency can further fortify the explanation with significant positive relationship between grain yield and yield attributes namely effective tillers $\left(\mathrm{r}=0.99^{* *}\right)$, grains per spike $(\mathrm{r}=0.97 * *)$ and test weight $\left(\mathrm{r}=0.96^{* *}\right)$ (Table 3$)$.

The increase in irrigation number from zero to six irrigations increased the grain yield of wheat by about $40.52 \%$. This increase was because of increased yield attributes viz., effective tillers $/ \mathrm{m}^{2}$, grains/earhead and 1000 grain weight. The stronger source is required for the stronger sink. The higher biological yield was found significantly associated with the higher grain yield $(\mathrm{r}=0.99 * *)$. This clearly shows that the biological yield increased by any input or management practice will automatically increase the grain yield of wheat. The grain yield of wheat can also be estimated through biological yield with the regression equation (Fig. 1, grain yield $=2.852+0.397$ biological yield, $\left.\mathrm{r}^{2}=0.98\right)$. Both Pusa Hydrogel and Herbal Hydrogel had not influenced the grain as well as biological yield of wheat.

\section{Economics}

Irrigation and hydrogel treatments have an impact on the cost of cultivation, gross returns, net monetary returns and BC ratio. Among different irrigation levels, based on the means of two year data, the maximum cost of cultivation (Rs. 68868/ha), gross returns (Rs. 129785/ha), net monetary returns (Rs. 60917/ha) and BC ratio (1.88) were recorded with the application six irrigations at CRI, TL, JT, FL, milking and dough stage followed by three irrigations at 40, 80 and 120 DAS with values of Rs. 65212 cost of cultivation, Rs. 117215 gross returns, Rs. 52003/ha net returns and BC ratio of 1.88 and minimum values for cost of cultivation (Rs. 61556/ha), gross returns (Rs. 76784/ ha) and net returns (Rs. 15229/ha) and $\mathrm{BC}$ ratio (1.24) were recorded under without irrigation 
treatment (Table 4). The application of six irrigation at CRI, TL, JT, FL, milking and dough stage increased gross and net returns by 40.84, 13.17 and $9.69 \%$ and $75.00,22.06$ and $14.63 \%$ over no irrigation, three irrigations at CRI, LT and GF and three irrigations at 40, 80 and 120 DAS, respectively. Similarly with the application of three irrigations at CRI, LT and GF and three irrigations at 40,80 and 120 DAS resulted in 31.86 and $34.49 \%$ higher gross, and 67.92 and $70.71 \%$ higher net returns compared to without irrigation, respectively. This scenario was basically because of the higher grain yield and biological yield in six irrigations at CRI, TL, JT, FL, milking and dough stage, three irrigations at CRI, LT and GF and three irrigations at 40, 80 and 120 DAS treatments compared to the other treatments. Among sub plot treatments, there was not much difference was observed with the application of Pusa and Herbal hydrogel treatments in terms of gross and net return and $\mathrm{BC}$ ratio. Maximum cost of cultivation (Rs. 66886/ha) and gross return (Rs. 110392/ha) was found in Pusa hydrogel treatment, whereas, highest net return (Rs. 44401) was recorded with the application of Herbal hydrogel treatment. Minimum net return (Rs. 43811/ha) was recorded in without hydrogel treatment. Highest BC ratio with value of 1.67 was found in control and herbal hydrogel treatment. Hence, application of Pusa and Herbal hydrogels didn't provide much additional income over without application. The higher crop productivity might be the principal reason for higher net returns with application of six irrigations. Similar results of higher gross and net income with the application of six irrigations were also reported by Kumar et al. (2019) ${ }^{[10]}$.

Table 1: Effect of different irrigation levels and hydrogel treatments on growth, yield attributes and grain yield of wheat (pooled means of 201617 and 2017-18 data)

\begin{tabular}{|c|c|c|c|c|c|c|}
\hline Treatments & Plant height $(\mathrm{cm})$ & $\begin{array}{l}\text { Effective } \\
\text { tillers/m }\end{array}$ & $\begin{array}{c}\text { Grains/ } \\
\text { earhead }\end{array}$ & $\begin{array}{c}\text { 1000-grain } \\
\text { weight }(g)\end{array}$ & $\begin{array}{c}\text { Grain yield } \\
(\mathrm{q} / \mathrm{ha})\end{array}$ & Biological yield (q/ha) \\
\hline \multicolumn{7}{|l|}{ Level of Irrigations } \\
\hline No irrigation & 82.67 & 258.45 & 51.63 & 37.53 & 36.94 & 84.72 \\
\hline Three irrigations (CRI, LT and GF) & 96.72 & 365.83 & 55.43 & 38.44 & 52.90 & 129.82 \\
\hline Three irrigations (35/40 DAS, 80 DAS, 120 DAS) & 97.75 & 375.83 & 57.09 & 39.07 & 55.87 & 132.59 \\
\hline Six irrigations (CRI, TL, JT, FL, MI and Dough stage) & 100.94 & 406.67 & 59.43 & 39.53 & 62.11 & 146.54 \\
\hline S. Em \pm & 0.72 & 4.37 & 0.55 & 0.20 & 0.69 & 1.59 \\
\hline $\operatorname{LSD}(\mathrm{P}=0.05)$ & 2.54 & 15.40 & 1.95 & 0.70 & 2.44 & 5.62 \\
\hline \multicolumn{7}{|l|}{ Hydrogel Treatments } \\
\hline Control & 94.44 & 348.83 & 55.28 & 38.55 & 51.31 & 121.94 \\
\hline Pusa Hydrogel @ 2.5 kg/ha & 94.67 & 355.05 & 56.27 & 38.72 & 52.55 & 124.90 \\
\hline Herbal Hydrogel & 94.46 & 351.25 & 56.14 & 38.66 & 52.01 & 123.42 \\
\hline S. Em \pm & 0.42 & 5.38 & 0.40 & 0.19 & 0.55 & 1.26 \\
\hline $\operatorname{LSD}(\mathrm{P}=0.05)$ & NS & NS & NS & NS & NS & NS \\
\hline
\end{tabular}

Whereas, CRI=Crown Root Initiation, TL=Tillering, LT=Late Tillering, FL=Flowering, MI=Milking and GF=Grain Filling

Table 2: Interaction effect of different hydrogel on grain yield of wheat under different levels of irrigation (pooled means of 2016-17 and 201718)

\begin{tabular}{|c|c|c|c|c|}
\hline Level of Irrigations & \multicolumn{5}{|c|}{ Hydrogel Treatments } \\
\hline & Control & Pusa Hydrogel & Herbal Hydrogel & Mean \\
\hline No irrigation & 35.10 & 38.04 & 37.69 & 36.94 \\
\hline Three irrigations (CRI, LT and GF) & 51.71 & 53.49 & 53.50 & 52.90 \\
\hline Three irrigations (35/40 DAS, 80 DAS, 120 DAS) & 56.24 & 56.15 & 55.22 & 55.87 \\
\hline Six irrigations at (CRI, TL, JT, FL, MI and Dough stage) & 62.18 & 62.53 & 61.62 & 62.11 \\
\hline Mean & 51.31 & 52.55 & 52.01 & \\
\hline LSD (P=0.05) & & \multicolumn{5}{|c|}{2.44} \\
\hline Level of Irrigations & \multicolumn{5}{|c|}{ NS } \\
\hline Hydrogel Treatments & \multicolumn{5}{|c}{ NS } \\
\hline B within A & \multicolumn{5}{|c|}{} \\
\hline A within B & \multicolumn{5}{|c|}{} \\
\hline
\end{tabular}

Table 3: Correlation coefficient (r) between growth, yield and yield attributes of wheat

\begin{tabular}{|c|c|c|c|c|c|c|}
\hline & Grain yield & Biological yield & Plant height & Effective tillers/m & Grains/ earhead & 1000-grains weight \\
\hline Grain yield & 1.000 & & & & & \\
\hline Biological yield & $0.994^{* *}$ & 1.000 & & & & \\
\hline Plant height & $0.985^{* *}$ & $0.994^{* *}$ & 1.000 & & & \\
\hline Effective tillers/m & $0.994^{* *}$ & $0.999^{* *}$ & $0.995^{* *}$ & 1.000 & & \\
\hline Grains/earhead & $0.979^{* *}$ & $0.956^{* *}$ & $0.937 * *$ & $0.954 * *$ & 1.000 & \\
\hline 1000 -grains weight & $0.963^{* *}$ & $0.938^{* *}$ & $0.919^{* * *}$ & $0.941^{* *}$ & $0.972^{* *}$ & 1.000 \\
\hline
\end{tabular}

Whereas **, * = Significant at 1 and $5 \%$ of probability levels, respectively 
Table 4: Effect of irrigation levels and hydrogels on the economics of wheat (pooled mean of 2016-17 and 2017-18)

\begin{tabular}{|c|c|c|c|c|}
\hline Treatments & Cost of cultivation (₹/ha) & Gross return (₹/ha) & Net return (₹/ha) & BC ratio \\
\hline \multicolumn{5}{|l|}{ Level of Irrigations } \\
\hline No irrigation & 61556 & 76784 & 15229 & 1.24 \\
\hline Three irrigations (CRI, LT and GF) & 65212 & 112687 & 47476 & 1.72 \\
\hline Three irrigations (35/40 DAS, 80 DAS, 120 DAS) & 65212 & 117215 & 52003 & 1.79 \\
\hline Six irrigations (CRI, TL, JT, FL, MI and Dough stage) & 68868 & 129785 & 60917 & 1.88 \\
\hline \multicolumn{5}{|l|}{ Hydrogel Treatments } \\
\hline Control & 64011 & 107823 & 43811 & 1.67 \\
\hline Pusa Hydrogel & 66886 & 110392 & 43505 & 1.64 \\
\hline Herbal Hydrogel & 64736 & 109138 & 44401 & 1.67 \\
\hline
\end{tabular}

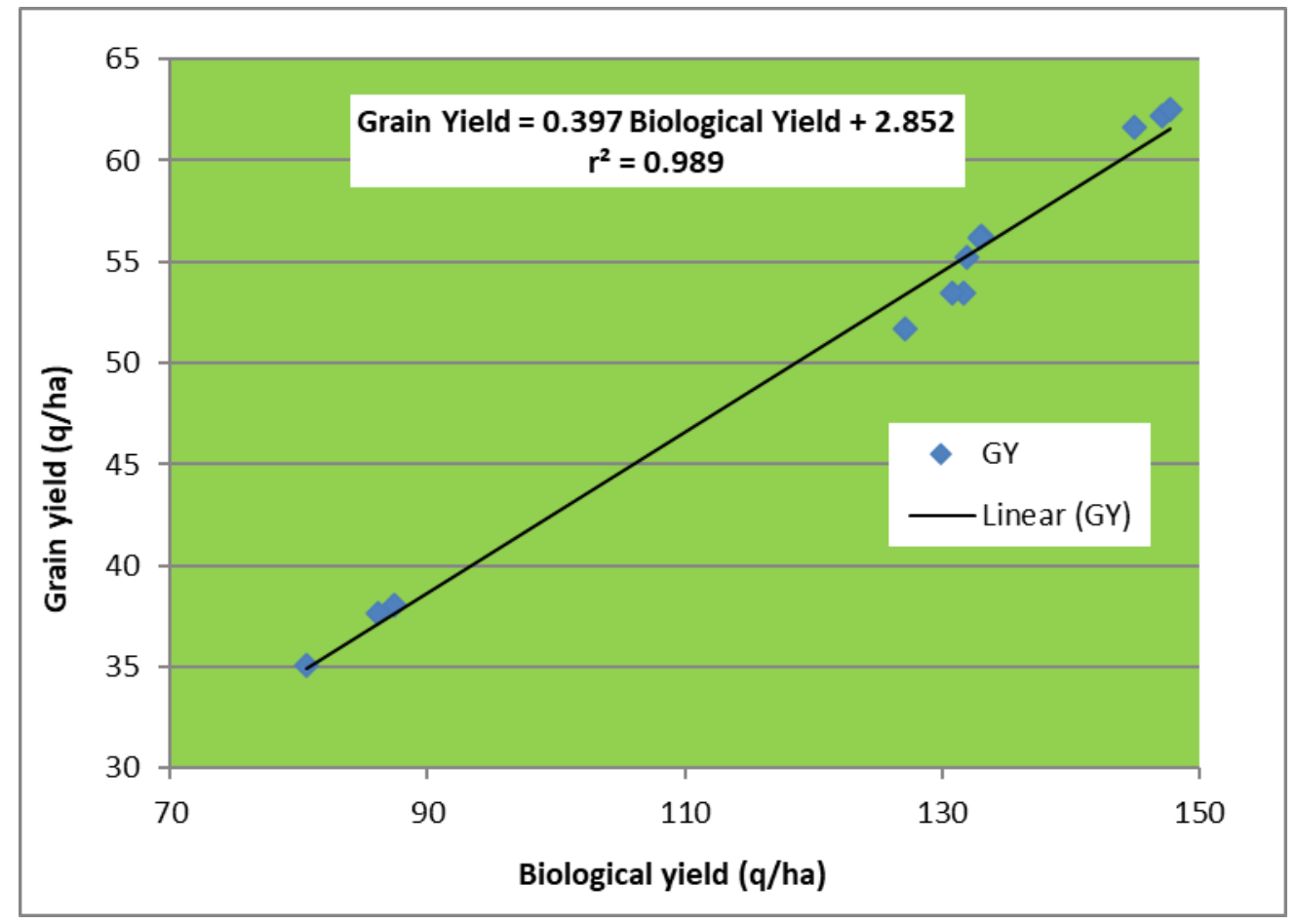

Fig 1: Regression line showing the relationship of biological yield ( $\mathrm{kg} / \mathrm{ha})$ with grain yield $(\mathrm{kg} / \mathrm{ha})$.

\section{Conclusion}

The results of this experiment during Rabi 2016-17 and 201718 seasons concluded that growing of wheat crop with the application of six irrigations at all important crop growth stages i.e. crown root initiation, tillering, jointing, flowering, milking and dough stages resulted in significant improvement in the growth, yield attributes, yield and profitability of wheat. However, with the application of Pusa Hydrogel and Herbal Hydrogel didn't cause any significant improvement in yield and profitability of wheat crop.

\section{References}

1. Anupama, Parmar BS. Pusa hydrogel-An indigenous semisynthetic superabsorbent technology for conserving water and enhancing crop productivity. Success Story 14, IARI, New Delhi, 2012.

2. Dabhi R, Bhatt N, Pandit B. Super absorbent polymersAn innovative water saving technique for optimizing crop yield. International Journal of Innovative Research in Science, Engineering and Technology. 2013; 2(10):53335340.

3. Dar SB, Ram H. Growth analysis, micro-climatic parameters and productivity of wheat (Triticum aestivum L.) in relation to hydrogel under different irrigation regimes and nutrient levels. Journal of Wheat Research. 2016; 8(1):59-62
4. Ekebafe LO, Ogbeifun DE, Okieimen FE. Polymer applications in agriculture. Biokemistri. 2011; 23(2):8189.

5. Gomez KA, Gomez AA. Statistical procedures for agricultural research (2 ed.). John wiley and sons, New York, 1984, 680.

6. Gora MK, Siddiqui MZ, Choudhary SL. Growth behavior of wheat cultivars under different irrigation levels. Int. J Curr. Microbiol. App. Sci. 2017; 6(9):195-199.

7. ICAR-IIWBR. Director's Report of AICRP on Wheat and Barley 2018-19, Ed: G.P. Singh. ICAR-Indian Institute of Wheat and Barley Research, Karnal, Haryana, India, 2019, 72

8. Karim MA, Hamid A, Rahman S. Grain growth and yield performance of wheat under subtropical conditions: II. Effect of water stress at reproductive stage. Cereal Res. Comm. 2000; 28:101-107.

9. Kumar M, Pannu RK, Singh B. Effect of irrigation regimes and nitrogen levels on phenology and grain yield of late sown wheat. Wheat and Barley Research. 2018; 10(1):151-155.

10. Kumar S, Sharma PK, Yadav MR, Sexena R, Gupta KC, Kumar $\mathrm{R}$ et al. Effect of irrigation levels and moisture conserving polymers on growth, productivity and proftability of wheat (Triticum aestivum). Indian Journal of Agricultural Sciences. 2019; 89(3):509-514. 
11. Lather VS. Novel herbal hydrogel - direct seeded rice technology for water- resources conservation. Acta Scientific Agriculture. 2019; 3(2):60-62.

12. Mehr MJZ, Kourosh K. Superabsorbent Polymer Materials: A Review. Iranian Polymer Journal. 2008; 17(6):451-477.

13. Mogaddam H, Galavi M, Soluki M, Siahsar B, Sayed M, Mustaffa H. Effects of deficit irrigation on yield, yield component and some morphological traits of wheat cultivars under field conditions. International Journal of Agricultural Sciences. 2012; 2(6):825-831.

14. Mukesh, Pannu RK. Effect of irrigation and nitrogen levels on growth and yield of late sown wheat. Haryana $\mathbf{J}$ Agron. 2014; 30(2):119-124.

15. Narjary B, Aggarwal P, Singh A, Chakraborty D, Singh R. Water availability in different soils in relation to hydrogel application. Geoderma. 2012; 187:94-101.

16. Ngwako S, Mashiqa PK. The effect of irrigation on the growth and yield of winter wheat (Triticum aestivum L.) cultivars. Intl. J Agril. Crop Sci. 2013; 5(9):976-982.

17. Roy T, Kumar S, Chand L, Kadam DM, Bihari B, Shrimali SS et al. Impact of Pusa Hydrogel application on yield and productivity of rainfed wheat in North West Himalayan region. Current Science. 2019; 116(7):12371246.

18. Shirazi SM, Yusop Z, Zardari NH, Ismail Z. Effect of irrigation regimes and nitrogen levels on the growth and yield of wheat. Advances in Agriculture. 2014; 123:1-6.

19. Singh AS, Sharma R, Dubey S, Kumar V. Efficacy of pusa hydrogel and chitosan on wheat (Triticum aestivum L.) physiological and biochemical parameters under water deficit condition. Journal of Pharmacognosy and Phytochemistry. 2018; 7(5):1589-1591.

20. Taipodia R, Singh ND. Diverse irrigation levels with planting patterns and its effect on yield of maize (Zea mays L.). IOSR-J Agril Vet. Sci. 2013; 4(2):65-67. 